\title{
TINJAUAN HUKUM ISLAM TENTANG PRAKTIK JUAL BELI SAYUR MELALUI WAKÂLAH DI DESA KRISIK PONOROGO
}

\author{
M. Harir Muzakki \\ Sekolah Tinggi Agama Islam Negeri Ponorogo, Indonesia \\ E-mail: harir_zdz06@yahoo.com \\ Siti Nurhayati \\ Sekolah Tinggi Agama Islam Negeri Ponorogo, Indonesia \\ E-mail: sitinurhayati@gmail.com
}

\begin{abstract}
The article seeks to analyze the transaction of vegetables through wakalah method in Krisik Village Ponorogo from Islamic legal perspective. Wakâlah requires four important elements: the person who gives a trust (muwakkil), the trustee (muwakkal or wakil), the deed (muwakkal fîb), and the transaction statements (ijâb-qabui). The transaction of vegetables in Krisik Village is done in an unusual way. In many areas, the brokers usually buy all farmers' crops at once and pay for the farmers in-cash. In Krisik Village, the brokers, however, first of all, sell farmers' vegetables into markets. The brokers will pay the farmers for their vegetables afterward. It means that the brokers do not pay for the farmers in-cash. It is also found that the farmers and brokers in Krisik Village make an uncommon agreement ('aqd), in which they agree to reduce the scale. The practice seems to violate a number of Quranic verses, which ask people to enhance the scales. Such a practice of reducing scale has been a "common agreement" among the Krisik people for decades. On the one hand, the practice aims at preventing the brokers from loss, while on the other the farmers do not feel aggrieved from the reduction of the scale.
\end{abstract}

Keywords: Vegetables; 'aqd; price; scale; market.

\section{Pendahuluan}

Jual beli adalah perjanjian tukar menukar barang yang mempunyai nilai atas dasar kerelaan antara dua belah pihak untuk dimiliki sesuai dengan ketentuan sharî‘ah. Ketentuan sharî‘ah yang dimaksud adalah 
memenuhi syarat dan rukun jual beli, sehingga transaksi jual beli menjadi sah. Mengetahui tentang barang-barang yang benar-benar halal dan jauh dari unsur yang diharamkan oleh Allah adalah salah satu syarat dalam jual beli, selain syarat-syarat lainnya. ${ }^{1}$ Selain itu transaksi jual beli didasarkan pada asas suka sama suka ('an tarâd), terbuka dan bebas dari unsur penipuan untuk mendapatkan sesuatu yang ada manfaatnya dalam kehidupan dunia. Dasar 'an tarậ kaitannya dengan jual beli yakni ber dari kejujuran, kepercayaan dan ketulusan. Selain itu, transaksi jual beli belum dianggap sah apabila ijâb qabûl di antara pembeli dan penjual belum terjadi, karena ijâb qabûl merupakan salah satu rukun jual beli.

Untuk memperjelas hal-hal tersebut maka perlu diketahui batasan dalam melakukan aktivitas jual beli. Kejelasan tersebut mencakup, antara lain, harus diketahuinya bahwa barang yang diperjualbelikan adalah halal dan jauh dari unsur-unsur yang diharamkan oleh Allah. Selain itu harga barang juga harus jelas dan barang yang diakadkan ada di tangan untuk kemudian disertai dengan sighat al-'aqd. S. Sighat al-'aqd adalah pernyataan transaksi jual beli berupa ijâb (penyerahan) dan qabûl (penerimaan). ${ }^{3}$ Tiadanya kesepakatan antara ijâb dan qabûl dan tidak diketahuinya harga jual barang mengakibatkan batal atau tidak sahnya suatu transaksi jual beli. ${ }^{4}$

Untuk mempermudah transaksi jual beli, dilakukan apa yang dinamakan akad wakâlah. Wakâlah sendiri didefiniskan dengan "pelimpahan wewenang untuk melakukan tindakan kepada orang lain yang sesuai dengan sharî‘ah dan ketentuan yang telah ditentukan oleh kedua belah pihak untuk melakukan tindakan tertentu". 5 Seperti halnya dalam jual beli, dalam wakâlah juga terdapat unsur-unsur yang harus dipenuhi diantaranya adanya muwakkil yang disyaratkan harus memiliki otoritas penuh atas suatu pekerjaan yang akan dilimpahkan, adanya seorang wakîl yang disyaratkan cakap hukum, serta objek yang

\footnotetext{
1 Penjelasan lebih lanjut tentang rukun dan syarat jual beli, lihat Mardani, Fiqib Ekonomi Syariah (Jakarta: Kencana Prenada Media Group, Cet. 2, 2013), 104-105.

${ }^{2}$ Rahmat Syafe'i, Fiqih Muamalah (Bandung: Pustaka Setia, 2006), 46.

${ }^{3}$ Ibid.

4 Afzalur Rahman, Doktrin Ekonomi Islam IV (Yogyakarta: Dana Bakti Wakaf, 1996), 146.

${ }^{5}$ Ismail Nawawi, Fiqih Muamalah Klasik dan Kontemporer: Hukum Perjanjian, Ekonomi, Bisnis dan Sosial (Bogor: Ghalia Indonesia, 2002), 35.
} 
diwakilkan harus diketahui oleh wakîl dan sesuai dengan sharî‘ ah. ${ }^{6}$ Dalam suatu transaksi jual beli, termasuk wakâlah, terkadang penjual atau pembeli memberikan syarat agar transaksi menghasilkan kesepakatan yang dapat diterima oleh kedua belah pihak. Pada dasarnya, semua syarat yang dibuat adalah sah selama tidak bertentangan dengan shar.

Dalam jual beli dibutuhkan penetapan harga untuk mempermudah transaksi. Harga adalah suatu yang direlakan dalam akad, baik lebih sedikit, lebih besar atau sama dengan nilai barang. Biasanya harga dijadikan penukar barang yang diridhai oleh kedua pihak yang berakad. ${ }^{7}$ Harga dapat ditetapkan berdasarkan kualitas dan kuantitas barang, selain itu juga dipengaruhi oleh permintaan dan penawaran seperti halnya hukum permintaan (demand) dalam Ilmu Ekonomi yang berbunyi "Semakin tinggi suatu permintaan, harga cenderung naik dan, sebaliknya, semakin menurun suatu permintaan, harga akan cenderung turun".

Praktik jual beli sayur di Desa Krisik Kecamatan Pudak berbeda dari umumnya, yaitu petani menjual sayur ke tengkulak dengan harga sesuai dengan kesepakatan di awal akad. Setelah petani sayur menyerahkan dagangannya kepada tengkulak, pembayaran dilakukan setelah dagangan sayur tersebut dijual oleh tengkulak ke pasar. ${ }^{8}$ Yang membedakan praktik ini dari jual beli biasanya adalah ketika harga di pasar turun, maka tengkulak akan membayar sayur ke petani sesuai dengan harga di pasar, tidak seperti kesepakatan awal. Praktik transaksi tersebut belum jelas apakah termasuk jual beli atau wakâlah. Sekilas praktik tersebut seperti jual beli, tetapi jika diamati secara mendalam praktik tersebut nampak seperti wakâlah. Selain itu, tidak ada sîghat yang jelas dalam transaksi di atas, seperti petani menyatakan, "Aku wakilkan penjualan sayur ini kepadamu".

Dalam hukum Islam, jual beli bersyarat ada yang diperbolehkan dan tidak dibolehkan. Jual beli bersyarat tidak dibolehkan jika bertentangan dengan shar'. Dalam kasus praktik jual beli sayur di Desa Krisik disyaratkan adanya potongan timbangan, padahal Islam memerintahkan menyempurnakan timbangan. Hal ini sebagaimana ditegaskan dalam firman Allah dalam Q.S. al-Isrâ' [17]: 35 yang

\footnotetext{
6 Djuwaini Dhimyauddin, Pengantar Fiqih Muamalah (Yogyakarta: Pustaka Pelajar, 2008), 242.

${ }^{7}$ Syafe'i, Fiqih Muamalah, 87.

${ }^{8}$ Gito, Wawancara, Krisik, 20 Februari 2016.
} 
artinya: dan sempurnakanlah takaran dan timbangan dengan adil. Pemotongan timbangan, dengan demikian, jelas bertentangan dengan ketentuan shar: Pertanyaanya kemudian adalah "Apakah syarat semacam ini diperbolehkan atau tidak dalam fiqh?"

Persoalan lainnya adalah tentang penetapan harga sayur di Desa Krisik. Penentuan harga selalu berkaitan dengan penawaran dan permintaan, seperti halnya berlaku dalam hukum ekonomi yang disebut di atas. Meski demikian hukum tersebut tidak selalu berlaku dalam penetapan harga sayur di Desa Krisik. Harga sayur cenderung tetap tidak mengalami kenaikan (stagnant) walaupun permintaan tinggi dan barang mulai langka. Apakah ada campur tangan pihak yang ingin mendapatkan keuntungan yang sebesar-besarnya dengan merusak harga pasar, ataukah karena memang ada faktor-faktor lain yang mempengaruhi permintaan dan penawaran sehingga harga cenderung tetap??

Alasan pemilihan Desa Krisik Kecamatan Pudak sebagai lokus penelitian adalah karena tempat tersebut merupakan central sayur di Kabupaten Ponorogo. Tulisan ini akan membahas akad jual beli dan wakâlah, potongan timbangan dan penetapan harga dalam praktik jual beli sayur di Desa Krisik Kecamatan Pudak dalam tinjauan hukum Islam (fiqb).

\section{Gambaran Singkat Praktik Jual Beli Sayur di Desa Krisik}

Desa Krisik terletak di Kecamatan Pudak yang berjarak sekitar 30 $\mathrm{km}$ dari pusat pemerintahan Kabupaten Ponorogo. Lokasinya terletak di selatan lereng Gunung Wilis dan memiliki cuaca yang sangat sejuk. Desa Krisik terdiri dari beberapa areal persawahan, perkebunan, dan juga pemukiman penduduk. Perkebunan di Desa Krisik menghasilkan kurang lebih 1 ton sayur setiap harinya, yang kualitasnya cukup membanggakan penduduknya dan warga Ponorogo pada umumnya. Berbagai macam jenis sayuran seperti, kubis, wortel, sawi, jepan, buncis, bawang pre, bawang merah dan lain-lain sudah didistribusikan di pasar-pasar sekitar daerah Ponorogo bahkan sampai ke Karesidenan Madiun seperti Pacitan, Madiun dan Magetan.

Dilihat dari keadaan tanah dan banyaknya areal persawahan dan perkebunan, dipastikan bahwa penduduk Desa Krisik mayoritas adalah petani. Hal ini dibenarkan oleh orang nomor satu di Desa Krisik yang menjelaskan:

${ }^{9}$ Wahid, Wawancara, Krisik, 15 Februari 2016. 
Desa Krisik terdiri dari perkebunan dan sawah-sawah yang terhampar luas, sehingga kebanyakan penduduk Desa Krisik bermata pencaharian sebagai petani. Struktur tanah di Desa Krisik yang terbilang subur mendukung para petani untuk menanam sayur-sayuran. Selain itu, Desa Krisik berbatasan langsung dengan hutan yang banyak ditumbuhi rumput liar, sehingga petani tidak hanya bertani tetapi juga beternak sapi atau kambing. ${ }^{10}$

Hampir 98\% perekonomian masyarakat Desa Krisik bertumpu pada sektor pertanian dan, sesuai dengan penjelasan hasil wawancara di atas, peternakan. Pertanian di Desa Krisik lebih fokus pada tanaman sayuran karena masa panen sayur relatif lebih pendek dibanding dengan tanaman pertanian lain, semisal padi dan jagung. Oleh karena itulah petani lebih memilih menanam sayur daripada padi maupun jagung. Usia tanaman sayur yang pendek dan masa panen yang relatif singkat sangat mendukung pemenuhan kebutuhan hidup para petani dan tengkulak sayur. Semakin banyak dan baik panen yang didapat, semakin banyak pula keuntungan yang didapat petani dan tengkulak untuk memenuhi kebutuhannya, sehingga masyarakat Desa Krisik dapat hidup sejahtera.

Tingkat kesejahteraan masyarakat Desa Krisik Kecamatan Pudak bisa dikatakan cukup merata, walaupun masih ada sebagian kecil masyarakat Desa Krisik yang kurang mampu. Meski dikatakan masyarakat kurang mampu, namun mereka masih dapat memenuhi kebutuhan hidup dengan hasil menjadi buruh tani.

Praktik jual beli sayur di Desa Krisik sendiri telah berlangsung sejak penduduk mulai menanam sayur. Awalanya mereka diajari oleh petani dari Kabupaten Magetan. Petani tersebut mencontohkan bagaimana cara menanam sayur agar bisa mendapatkan hasil panen yang melimpah ruah. ${ }^{11}$ Saat itu belum banyak petani yang menanam sayur. Petani Desa Krisik kebanyakan masih menanam ketela pohon dan jagung, namun seiring berjalannya waktu mereka mulai menanam sayuran dalam skala kecil. Awalnya mereka membibit atau meminta benih sayur dengan jumlah kecil kepada petani lain yang telah menanam sayur sebelumnya untuk kemudian ditanam kembali. ${ }^{12}$ Meski demikian saat ini jarang sekali petani yang meminta benih sayur untuk ditanam. Sebagian besar orang lebih memilih membeli daripada meminta, karena sayur merupakan komoditi yang saat ini

${ }^{10}$ Warna (Kades Desa Krisik), W awancara, Krisik, 29 Februari 2016.

11 Ibid.

12 Ibid. 
diperjualbelikan dan sangat berharga bagi masyarakat Desa Krisik. Pelan namun pasti, hampir semua masyarakat Desa Krisik menjadi petani sayur, sehingga praktik jual beli sayur menjadi aktivitas pasti atau selalu ada setiap hari di desa tersebut.

Proses jual beli sayur dilakukan dengan cara petani menjual sayur kepada tengkulak dengan menawarkan terlebih dahulu sayur dagangan yang dijual lebih dari $30 \mathrm{~kg}$ dengan kesepakatan harga, jenis sayur yang ditawarkan dan kapan petani mengantar sayur tersebut ke rumah tengkulak. Petani menawarkan terlebih dahulu dagangannya ke tengkulak dengan shighah "Kapan memetik sayurku?" Meski demikian terkadang tengkulak ada yang datang langsung mengambil sayur tersebut ke rumah atau ke kebun petani, dan ada juga tengkulak yang mencari sayur petani yang sekiranya sudah panen dan ingin dijual agar tidak didahului oleh tengkulak lain. Hal ini penulis ketahui dari keterangan salah seorang informan yang mengatakan:

Petani biasanya datang ke rumah saya untuk menwarkan dagangannnya, dengan menanyakan dulu harga, kapan memetik sayur tersebut. Tetapi terkadang saya juga mencari-cari petani yang sedang panen agar tidak kedahuluan tengkulak lain. ${ }^{13}$

Dalam praktik jual beli sayur di Desa Krisik, kesepakatan akad adalah hal paling utama dan sangat penting, karena dari hal tersebut dapat diidentifikasi akad apa yang sedang dilaksanakan selain itu dapat dinilai sah atau tidak sahnya suatu transaksi. Keabsahan akad menunjukkan bahwa kedua belah pihak telah saling ridha dan saling menyetujui atas transaksi jual beli yang dilaksanakan. Petani dan tengkulak saling melakukan ijâb dan qabûl. Adanya ijâb dan qabûl tersebut menunjukkan bahwa di antara tengkulak dan petani ada 'an tarâd atas transaksi jual beli mereka, sehingga tidak ada pihak yang dirugikan.

Hal ini dapat diketahui dari adanya proses tawar-menawar antara petani dan tengkulak, yang meliputi hal-hal yang perlu diketahui oleh kedua belah pihak seperti harga, waktu pengantaran barang (sayur) dan waktu penyerahan uang. Ijâb dan qabûl antara tengkulak hanya dilakukan secara lisan dan tidak menggunakan perjanjian tertulis yang menandakan bahwasanya telah terjadi kesepakatan antara tengkulak dan petani. Hal ini berdasarkan penjelasan dari seorang informan:

Ijâb qabûl yang kami laksanakan itu hanya lisan saja tidak menggunakan surat, tapi seiring perkembangganya teknologi

${ }^{13}$ Wahid, Wawancara. 
biasanya saya meng-SMS atau telfon tengkulak. Jadi kesepakatan kami terus terjadi walaupun saya tidak berhadap-hadapan dengan tengkulak. Ketika saya menjual sayur tidak pernah saya memperoleh uang secara langsung, pasti menungggu terlebih dahulu setelah sayur laku dijual di pasar. ${ }^{14}$

Jika sayur tersebut tidak dalam jumlah besar, misalnya hanya $20 \mathrm{~kg}$ dan harga sayur berkisar antara Rp. 2000-Rp. 3000/kg, tengkulak akan membayar langsung kepada petani. Tetapi jika petani menjual sayur dalam jumlah besar atau sedikitnya $30 \mathrm{~kg}$, pembayaran akan diberikan setelah sayur terjual di pasar. Hal tersebut dilakukan karena harga sayur sering mengalami fluktuasi, sehingga apabila dibayar terlebih dahulu dan harga dalam keadaan turun maka tengkulak akan mengalami kerugian besar, padahal tengkulak beranggapan telah membantu petani menjualkan sayurnya ke pasar. Jika harga di pasar mengalami penurunan, tengkulak akan membayar sayur petani sesuai harga pasar bukan berdasarkan harga yang ditentukan ketika sayur ditawarkan pada tengkulak. Namun demikian ada juga tengkulak yang membayar sesuai kesepakatan awal, kecuali sayur dari petani mengalami kerusakan maka tengkulak akan membayar separuh harga. Hal tersebut dilakukan karena sayur yang rusak terkadang tidak laku dan kalaupun laku biasanya dengan harga di bawah standar.

Tengkulak merupakan perantara petani untuk menjual sayurnya ke pasar. Jika petani menjual sayurnya langsung ke pasar, mereka akan mengalami kesulitan karena pembeli di pasar tidak mampu membeli dengan jumlah besar. Hal ini karena biasanya petani menjual sayur dalam skala besar sekaligus untuk memperkecil tenaga dan biaya yang dikeluarkan. Selain itu jika petani menjual sendiri sayurnya ke pasar, biaya yang dikeluarkan justru lebih besar seperti biaya transportasi dan pengepakan serta rawannya mereka tertipu oleh pedagang nakal yang ada di pasar. Berdasarkan hal inilah peran tengkulak sangat dibutuhkan oleh petani, sehingga timbul ketergantungan yang saling menguntungkan (mutualisme) antara kedu pihak.

\section{Praktik Akad Jual Beli Sayur di Desa Krisik}

Akad merupakan perjanjian atau kesepakatan yang memuat ijâb (penawaran dari penjual) dan qabûl (penerimaan bagi pihak pembeli) antara satu pihak dengan pihak yang lain yang berisi hak dan

${ }^{14}$ Waris, Wawancara, Krisik, 29 Februari 2016. 
kewajiban masing-masing pihak sesuai dengan prinsip sharı̂‘ ${ }^{6} .^{15}$ Dalam praktik jual beli sayur di Desa Krisik, seorang petani mewakilkan urusan jual beli sayur kepada tengkulak, bukan karena petani tidak mampu menjual tetapi dikarenakan cara tersebut dianggap lebih mudah. Di samping itu, jarak Desa Krisik jauh dari pasar.

Petani memandang mewakilkan jual beli sayur kepada tengkulak merupakan solusi yang tepat dalam menjual sayur dalam jumlah besar. Petani juga tidak perlu mengeluarkan biaya transportasi untuk membawa sayurnya ke pasar. Dengan adanya kesepakatan antara petani dalam akad jual beli maupun wakâlah, petani harus menerima ketentuan dari tengkulak diantaranya "pemotongan timbangan" dalam akad wakâlah maupun jual beli, dan pembayaran di akhir serta pembayaran sesuai harga pasar karena pembayaran diberikan setelah sayur dijual di pasar. ${ }^{16}$

Praktik jual beli sayur di Desa Krisik Kecamatan Pudak merupakan salah satu bentuk perjanjian dalam fiqh yang bertujuan untuk memenuhi kebutuhan hidup antar sesama manusia. Transaksi objek jual beli tersebut sudah menjadi kebiasaan umum yang dilakukan oleh masyarakat. Untuk mengetahui praktik jual beli sayur ini sah atau tidak perlu diketahui terlebih dahulu syarat dan rukun yang harus dipenuhi dalam praktik jual beli dan wakâlah.

1. Dilihat dari segi subjek

Subjek jual beli sayur melalui wakâlah di Desa Krisik adalah petani dan tengkulak, di mana petani sebagai pihak penjual dan selaku pihak yang mewakilkan (muwakki) penjualan sayur kepada tengkulak sedangkan tengkulak sebagai pihak pembeli dan wakil yang menjualkan sayur petani ke pasar. Jual beli yang dilakukan oleh kedua belah pihak dikatakan sah jika telah memenuhi syarat dan rukunnya. Dalam jual beli, tengkulak dan petani disebut âqidayn. ${ }^{17}$

Praktik jual beli ini dikatakan wakâlah karena petani mewakilkan penjualan sayur ke pasar kepada tengkulak. Tengkulak dalam akad wakâlah adalah sebagai wakîl petani yang merupakan salah satu rukun

15 Ahmad Azhar Basyir, Asas-asas Hukum Muamalah Hukum Perdata Islam (Yogyakarta: UII Press, 2000), 11.

16 Darmi, Wawancara, Krisik, 29 Februari 2016.

17 Syarat áqidayn dalam transaksi jual beli: bukan dipaksa (atas kesadaran dan kehendaknya sendiri), sehat akalnya, orang yang gila atau bodoh tidak sah jual belinya, sudah mencapai umur atau bâligh. Lihat Sudarsono, Pokok-Pokok Hukum Islam (Jakarta: Raja Grafindo Persada, 2002), 121. 
dari akad wakâlah dengan syarat harus berakal ${ }^{18}$ dan orang yang sah melakukan urusan yang dilimpahkan, atas namanya sendiri. Petani sebagai muwakkil juga harus memenuhi syarat diantaranya orang yang sah melakukan sendiri urusan yang yang ia limpahkan kepada orang lain, baik karena faktor kepemilikan maupun sebagai orang yang cakap hukum. ${ }^{19}$

Penjual sayur (petani) dan pembeli sayur (tengkulak) adalah orang yang sudah cakap umur karena rata-rata berumur 24-50 tahun. Keduanya bisa membedakan akad tersebut bermanfaat atau tidak dan akad tersebut dilakukan untuk memenuhi kebutuhan hidup. Di satu sisi, penjual mampu memilih tengkulak mana yang bisa menjualkan sayurnya. Di sisi lain, tengkulak mampu memilih sayur yang kualitasnya baik, kalaupun kualitasnya kurang baik tengkulak mampu memberikan harga sesuai dengan nilai barang. Kedua belah pihak telah bertindak sesuai dengan hukum. Artinya, keduanya telah dewasa atau bâligh dan tidak dalam keadaan mabuk maupun gila, atas kesadaran dan kehendaknya sendiri, tidak ada paksaan dan keduanya melakukan atas dasar 'an tarâd. Dalam pandangan fiqh, syarat 'âqidayn dalam praktik jual beli sayur di Desa Krisik, dengan demikian, telah terpenuhi, sehingga akad jual beli tersebut sah menurut subjeknya.

Dari sisi wakâlah, petani dan tengkulak selain bertindak sebagai'âqidayn, keduanya juga bertindak sebagai muwakkil dan wakîl karena adanya pembayaran di akhir setelah sayur dijual ke pasar oleh tengkulak, dan harga disesuaikan dengan harga pasar. ${ }^{20}$ Petani sebagai muwakkil merupakan orang yang sudah bâligh dan mampu melakukan hal tersebut berdasarkan hak kepemilikan. Petani memetik sayur dari kebunnya sendiri yang belum pernah ditawarkan maupun dijual kepada pihak lain. Kepemilikan sayur berada di tangan petani, sehingga petani telah memenuhi syarat sebagai subjek muwakkil.

Tengkulak bertindak sebagai wakîl karena bertugas menjual sayur petani ke pasar sesuai dengan kesepakatan awal antara petani dengan tengkulak. Tengkulak merupakan orang dewasa yang mampu membedakan hal yang baik dan buruk bagi dirinya sehingga memenuhi persyaratan bâligh. Tengkulak juga bisa menjualkan sayur petani ke pasar sesuai dengan kesepakatan awal, meskipun terkadang

\footnotetext{
${ }^{18}$ Hendi Suhendi, Fiqib Muamalah (Jakarta: Rajawali Press, Cet. 8, 2013), 235.

19 Tim Laskar Pelangi, Metodologi Fiqih Muamalab: Diskursus Metodologis Konsep Interaksi Sosial Ekonomi, Cet. 2 (Kediri: Lirboyo Press, 2013), 207.

${ }^{20}$ Ratmi, Wawancara, Krisik, 17 Februari 2016.
} 
keadaan harga pasar berubah (tidak sesuai dengan kesepakatan). ${ }^{21} \mathrm{Hal}$ ini menandakan bahwa tengkulak mampu melaksanakan amanat yang dilimpahkan oleh petani, yang artinya tengkulak telah memenuhi persyaratan sebagai wakîl.

Menurut al-Shâfîîyah, ‘áidayn disyaratkan harus beragama Islam. ${ }^{22}$ Berdasarkan dokumen Sekretaris Desa diketahui bahwa semua penduduk Desa Krisik beragama Islam. ${ }^{23}$ Sementara itu menurut alHanafiyah, âqidayn tidak disyaratkan harus bâligh, tetapi yang penting mumayyiz (bisa membedakan hal-hal yang baik dan buruk). Dengan demikian, petani dan tengkulak yang melakukan praktik jual beli sayur telah memenuhi persyaratan jual beli dan wakâlah berdasarkan subjeknya.

2. Dilihat dari segi objek

Barang yang menjadi objek akad (ma'qûd 'alayh) dalam praktik jual beli terlebih dahulu haruslah diketahui kadar, sifat, wujud, dan diketahui pula masanya, serta dapat diserahterimakan. Objek berada dalam kepemilikan satu pihak sehingga dapat terhindar dari kesamaran riba. Hukum Islam melarang memperjualbelikan barang yang dikategorikan barang najis atau diharamkan oleh shar', seperti darah, bangkai, dan babi. Jumbûr ulama telah menetapkan beberapa syarat objek atau barang yang akan diperjualbelikan. Syarat tersebut ada enam, tetapi sebagian ulama berpendapat bahwa syarat objek jual beli ada empat dan keempat syarat tersebut mencakup keenam syarat tersebut. $^{24}$

Pertama adalah suci zatnya. ${ }^{25}$ Dalam praktik jual beli sayur di Desa Krisik barang yang dijadikan objek adalah berbagai jenis sayur, seperti kubis, wortel, sawi, labu siam, dan buncis. Sayur bukanlah barang najis maupun barang yang diharamkan oleh shar. Semua sayur tersebut merupakan barang yang suci. Kedua, bermanfaat barangnya. ${ }^{26}$ Sayur merupakan makanan yang bergizi, sehingga bermanfaat untuk

\footnotetext{
${ }^{21}$ Katemi, Wawancara, Krisik, 26 Februari 2016.

22 Ibnu Mas'ud dan Zainal Abidin, Fiqih Madrab Syafi'i Buku 2: Muamalah, Munakahat, Jinayat (Bandung: Pustaka Setia, 2007), 28.

23 Dokumentasi Sekdes Desa Krisik Kecamatan Pudak, Format Isian Data Potensi Desa dan Kelurahan Tabun 2015.

${ }^{24}$ Qomarul Huda, Fiqih Muamalah (Yogyakarta: Teras, 2011), 62.

${ }^{25}$ Sayyid Sabiq, Fiqih Sunnah, Vol. 12, terj. Kamaludin A. Marzuki (Bandung: AlMa'arif, 1987), 52.

${ }^{26}$ Ibid.
} 
kesehatan tubuh. Ketiga, milik penjual. ${ }^{27}$ Sayur yang dijual oleh petani adalah milik petani sendiri yang berasal dari hasil panennya.

Keempat, barangnya ada atau tidak ada di tempat, tetapi pihak penjual menyatakan kesanggupannya untuk mengadakan barang itu. ${ }^{28}$ Dalam hal ini, petani langsung mengantarkan sayur kepada tengkulak jika beratnya kurang dari $20 \mathrm{~kg}$. Namun jika beratnya melebihi $20 \mathrm{~kg}$, petani menawarkan terlebih dahulu sayur yang akan dijual kepada tengkulak. Terkait waktu pengantaran sayur ke tengkulak, disepakati oleh kedua pihak. Artinya, objek atau barang yang diperjualbelikan memang ada dan petani selaku penjual sanggup mengadakan sayur ketika tengkulak membutuhkan barang tersebut. ${ }^{29}$

Kelima, barang dapat diserahterimakan. ${ }^{30}$ Petani menyerahkan sayurnya kepada tengkulak setelah dilakukan penimbangan dan didilakukan oleh kedua belah pihak. ${ }^{31}$ Keenam, barang dengan harga yang maklum (seimbang). ${ }^{32}$ Sayur mayur dibeli oleh tengkulak sesuai dengan harga pasar dan disesuaikan dengan biaya-biaya yang dikeluarkan untuk pengelolaan sayur-sayur tersebut, sehingga harga sayur mayur tersebut dinilai maklum karena harga telah ditentukan oleh pasar bukan tengkulak.

Dari salah satu syarat jual beli di atas dapat dinyatakan bahwa barang atau objek jual beli bisa diserahterimakan. Walaupun sayur tersebut telah diserahterimakan, tengkulak tidak langsung membayar sayur tersebut terutama jika sayur yang dijual oleh petani kurang dari $20 \mathrm{~kg}$. Akan tetapi jika sayur yang dijual lebih dari $20 \mathrm{~kg}$ dan harga di atas Rp. 2000 atau Rp. 2500, maka akan dibayar setelah sayur dijual di pasar oleh tengkulak. Praktik seperti ini dilakukan sejak dahulu, meski masyarakat Desa Krisik juga tidak mengetahui secara pasti sejak kapan praktik jual beli semacam ini dimulai. Selain itu jika sayur yang dijual petani di pasar mengalami penurunan harga, tengkulak akan membayar sayur petani sesuai harga pasar bukan berdasarkan kesepakatan awal. ${ }^{33}$

\footnotetext{
${ }^{27}$ Ibid.

28 M. Ali Hasan, Berbagai Macam Transaksi dalam Islam, Cet. 2 (Jakarta: Raja Grafindo Persada, 2004), 123.

${ }^{29}$ Darmi, Wawancara.

${ }^{30}$ Ibid.

${ }^{31}$ Waris, Wawancara.

32 Ibid.

33 Wahid, Wawancara.
} 
Dilihat dari pembayaran yang dilakukan di akhir, praktik jual beli sayur ini seperti menggunakan akad utang piutang. Akan tetapi dalam akad utang piutang, pembayaran adalah sama dengan apa yang dijanjikan di awal atau sesuai jumlah harga sayur yang dijual oleh petani. Namun dalam kenyataannya, pembayaran jual beli sayur sangat tergantung pada harga pasar dan terkadang tidak sesuai dengan harga awal yang telah disepakati oleh petani dan tengkulak.

Praktik jual beli dengan cara petani mewakilkan penjualan sayur kepada tengkulak untuk menjual sayurnya ke pasar dengan ketentuan harga yang telah disetujui oleh keduanya sama dengan akad wakâlah. Mewakilkan suatu urusan dengan adanya ketentuan-ketentuan yang harus dipenuhi oleh seorang wakîl disebut akad wakâlat muqayyadah. ${ }^{34}$ Akad wakâlah hukumnya sah jika memenuhi syarat-syarat wakâlah, diantaranya syarat dari segi objek wakâlah. Objek praktik jual beli sayur di Desa Krisik menurut hukum fiqh dipandang sah, karena sudah memenuhi persyaratan objek dalam jual beli. Begitu pula jual beli yang merupakan muwakkil fíh telah memenuhi persyaratan wakâlah dalam hal objeknya.

3. Dilihat dari sighah atau lafal ijâb dan qabûl

Jual beli belum bisa dikatakan sah sebelum adanya perkataan ijâb dan qabûl, sebab ijâb dan qabûl menunjukkan kerelaan. ${ }^{35}$ Pada dasarnya, ijâb dan qabûl dilakukan dengan lisan. Jika tidak memungkinkan karena adanya unsur yang menjadikan sebab penghalang, misalnya bisu atau yang lainnya, ijâb dan qabûl boleh dilakukan dengan surat menyurat. Isinya menandakan adanya serah terima atau kata-kata sepakat untuk melakukan transaksi di antara kedua belah pihak yang bertransaksi. ${ }^{36}$

Petani dan tengkulak Desa Krisik dalam hal sighhat ijâb qabûl lisan maupun tulisan tidak secara langsung menjelaskan akad apa yang digunakan atau berlangsung saat ini, karena petani dalam sighabnya hanya mengatakan: "Kapan memetik sayurku?"/Kapan giliranku"/"Besok memetik sayurku, ya!"37

Petani tidak menggunakan sîghah, seperti "Aku menjual sayurku kepadamu" atau "Aku wakilkan penjualan sayur ini kepadamu". Meski ada juga petani yang menawarkan sayurnya secara jelas mengatakan

\footnotetext{
34 Tim Laskar Pelangi, Metodologi Fiqih Muamalah, 213.

${ }^{35}$ Mas'ud, Fiqih Madzab Syafi'i, 27.

${ }^{36}$ Huda, Fiqib Muamalah, 56.

${ }^{37}$ Ratmi, Wawancara.
} 
"Aku jual sayur ini kepadamu". Akan tetapi hal ini terjadi hanya jika sayur yang dijual adalah $20 \mathrm{~kg}$ atau kurang. Berbagai macam sigh yang demikian, bagaimanapun, tetap menunjukkan maksud dari petani bahwa ia ingin menjual atau mewakilkan penjualan sayurnya kepada atau oleh tengkulak. ${ }^{38}$

Sighah merupakan suatu cara yang digunakan untuk menyatakan ijâb dan qabûl dalam sebuah perjanjian. Dalam menyatakan ijâb dan qabûl tidak ada ketentuan khusus yang mengatur, yang paling penting adalah maksud dari akad tersebut dapat dipahami oleh kedua belah pihak yang berakad. Şighah akad dapat dilakukan dengan cara lisan, tulisan, atau isyarat yang memberikan pengertian dengan jelas bahwa adanya ijâb dan qabûl, dan bisa pula berupa perbuatan yang telah menjadi kebiasaan dalam jual beli. ${ }^{39}$

Dalam fiqh, agar akad benar-benar mempunyai akibat hukum terhadap objek akad, diperlukan beberapa syarat yaitu:

Pertama, ijâb dan qabûl harus bersambung, sehingga bila seseorang yang berijab sudah berpisah sebelum adanya qabûl, maka ijâb tersebut menjadi batal. ${ }^{40}$ Dalam praktik jual beli sayur di Desa Krisik, akad atau kesepakatan transaksi dilakukan bersama antara tengkulak dengan petani secara langsung berhadapan (face to face). Akhir-akhir ini, petani dan tengkulak lebih memilih transaksi melalui handphone baik berbicara secara verbal maupun menggunakan SMS karena dianggap lebih efisien. $^{41}$ Percakapan antara petani dan tengkulak tersebut menunjukkan telah tercapai kesepakatan mengenai harga, waktu mengantar sayur ke rumah tengkulak dan jumlah sayur yang harus dipetik. ${ }^{42}$ Kesepakatan ini dilakukan dalam satu waktu pada saat petani dan tengkulak melakukan percakapan melalui media handphone, baik pembicaraan verbal maupun SMS. Hal ini menunjukkan bahwa ijâb dan qabûl antara kedua pihak tersebut dilakukan secara langsung dan bersambung.

Kedua, antara ijâb dan qabûl harus sesuai. ${ }^{43}$ Ijâb dan qabûl yang dilakukan petani dan tengkulak adalah sesuai, karena petani menawarkan sayur untuk dijual atau mewakilkan penjualan sayur. Tengkulak menjawab dengan memberitahukan harga sayur sesuai

\footnotetext{
${ }^{38}$ Ibid.

${ }^{39}$ Basyir, Asas-Asas Hukum Muamalat, 44.

${ }^{40}$ Huda, Fiqih Muamalah, 32.

${ }^{41}$ Waris, Wawancara.

${ }^{42}$ Katemi, Wawancara.

${ }^{43}$ Ibid.
} 
jenis yang ditawarkan oleh petani, informasi tentang waktu mengantarkan sayur dan volume sayur yang akan dipetik. Artinya, petani dan tengkulak membicarakan suatu hal yang sejalur atau membicarakan topik yang sama, sehingga kedua belah pihak menghasilkan sebuah kesepakatan yang saling menguntungkan.

Ketiga, ijâb dan qabûl harus jelas maksudnya sehingga dapat dipahami oleh pihak yang melakukan akad. ${ }^{44}$ Ijâb dan qabûl antara petani dengan tengkulak, walaupun tidak secara jelas dikatakan menjual atau mewakilkan penjualan, tetapi kedua belah pihak samasama memahami sighhah yang digunakan, ${ }^{45}$ yaitu melakukan praktik jual beli sesuai kebiasaan yang berlaku di masyarakat Desa Krisik. Praktik ini disebut 'urf laf:îy qawli, yaitu sebuah kebiasaan masyarakat dalam mempergunakan lafal tertentu dalam makna yang dipahami dan terlintas di pikiran masyarakat. ${ }^{46}$ Oleh karena itu tengkulak langsung memahami apa yang dimaksud oleh petani walaupun menggunakan sighah yang tidak langsung menjelaskan menjual atau mewakilkan.

Keempat, ijâb itu berjalan terus, tidak dicabut sebelum terjadi qabûl. ${ }^{47}$ Dalam praktik jual beli sayur di Desa Krisik, petani mengantarkan terlebih dahulu sayur yang telah dipanen ke rumah tengkulak dengan penetapan harga sesuai kesepakatan awal, ${ }^{48}$ tetapi untuk pembayarannya dilakukan setelah sayur dijual di pasar. Jadi tengkulak tidak langsung membayar sayur yang diantar petani ke rumah tengkulak. Walaupun pembayaran dilakukan dengan bertempo, tetapi pembayaran nantinya tidak ada nilai tambahan untuk masa atau waktu penjualan tengkulak di pasar. Metode pembayaran oleh tengkulak kepada petani dilakukan dengan cara seperti telah dijelaskan di atas, yaitu sesuai dengan volume sayur yang dijual oleh petani. Hal ini dilakukan karena harga sayur di pasaran cenderung bersifat fluktuatif. ${ }^{49}$

Akan tetapi jika kesepakatan jual beli dibatalkan, maka salah satu pihak yang membatalkan harus mengonfirmasi terlebih dahulu, sehingga tidak ada pihak yang dirugikan maupun dikecewakan. ${ }^{50}$ Dengan demikian diketahui bahwa ijâb dan qabûl dalam praktik jual

\footnotetext{
${ }^{44}$ Syafe'i, Fiqih Muamalah, 51.

${ }^{45}$ Ratmi, Wawancara.

46 Suwarjin, Ushul Fiqih (Yogyakarta: Teras, 2012), 149.

${ }^{47}$ Huda, Fiqib Muamalah, 33.

${ }^{48}$ Katemi, W awancara.

${ }^{49}$ Wahid, Wawancara.

${ }^{50}$ Waris, Wawancara.
} 
beli sayur di Desa Krisik berlangsung terus, artinya tengkulak dan petani berpisah setelah mereka mencapai kesepakatan untuk melakukan jual beli.

Penulis menyimpulkan bahwa dari segi akad telah memenuhi syarat dalam jual beli maupun jual beli yang diwakilkan, karena pada dasarnya syarat sebuah akad ijâb dan qabûl adalah sama. Praktik jual beli sayur di Desa Krisik merupakan praktik yang menggunakan dua metode tersebut (akad jual beli dan akad wakâlah). Menggunakan akad jual beli karena petani mengantarkan sayur secara langsung kepada tengkulak dan tengkulak membayarnya secara tunai, dan menggunakan akad wakâlah karena pembayaran dilakukan di akhir (setelah sayur terjual di pasar) tetapi tidak disertai penambahan dalam pembayaran. ${ }^{51}$ Praktik jual beli yang disebut terakhir termasuk dalam akad wakâlah, walaupun dalam sîghahnya tidak secara jelas disebutkan kata "mewakilkan". Meski demikian perbuatan kedua pihak (petani dan tengkulak) dapat dipahami sebagai akad wakâlah. Șighah, dalam konteks ini, tidak hanya disampaikan secara lisan, tetapi juga dengan perbuatan.

Selain itu praktik jual beli sayur di Desa Krisik telah sesuai dengan fiqh. Penjual dan pembeli telah membuat kesepakatan yang menunjukkan kerelaan antara keduanya, tidak ada unsur paksaan, dan praktik jual beli sayur semacam ini telah menjadi kebiasaan sejak awal di kalangan masyarakat Desa Krisik. Kebiasaan seperti ini disebut 'urf 'amali, yaitu kebiasaan masyarakat yang berkaitan dengan perbuatan biasa maupun muamalah keperdataan, ${ }^{52}$ sehingga bisa dijadikan sebuah landasan hukum jual beli. Hal ini juga sesuai dengan kaidah fiqh yang artinya, Adat istiadat itu bisa dijadikan dasar bukum, ${ }^{53}$ dan tidak bertentangan dengan al-Qur'ân maupun Hadîth.

\section{Potongan Timbangan Praktik Jual Beli Sayur di Desa Krisik}

Praktik jual beli sayur di Desa Krisik dilakukan oleh kedua belah pihak dengan proses tawar menawar terlebih dahulu, terkait harga, waktu memetik, dan volume sayur yang dipetik disertai dengan syarat yang diberikan oleh tengkulak kepada petani, yaitu syarat potongan timbangan. ${ }^{54}$ Saat ini pemotongan timbangan sering tidak disebutkan karena sudah menjadi kebiasaan masyarakat Desa Krisik. Namun

\footnotetext{
${ }^{51}$ Loso, Wawancara, Krisik, 27 Februari 2016.

${ }^{52}$ Suwarjin, Ushul Fiqih, 149.

53 Ibid., 151.

54 Wahid, Wawancara.
} 
demikian, petani melakukan praktik jual beli tersebut dengan 'an tarâd dan tanpa paksaan. ${ }^{55}$

Sayur-sayur yang diantar petani ke rumah tengkulak ditimbang dengan kesaksian tengkulak dan petani, ${ }^{56}$ kemudian dikenai syarat pemotongan timbangan seberat 2 s.d. $4 \mathrm{~kg}$ menyesuaikan kondisi dan berat sayurnya. Kondisi yang dimaksud dilihat dari bentuk sayur yang dijual oleh petani, yaitu jika sayur tersebut jelek, berukuran kecil-kecil, banyak tanahnya, dan dimakan ulat, maka akan dipotong lebih banyak dari sayur yang keadaanya bagus dan siap jual. ${ }^{57}$ Dalam jual beli, barang yang diperjualbelikan harus ditakar maupun ditimbang. Fiqh menetapkan bahwa jangan sampai ada penipuan dalam timbangan. Timbangan harus jelas, sesuai dan cocok serta jangan sampai dikurangi. Pemotongan timbangan dalam jual beli sayur di Desa Krisik merupakan sebuah kesepakatan kedua belah pihak. Hal semacam ini merupakan sebuah kebiasaan yang telah lama terjadi dan menjadi syarat dalam praktik jual beli sayur di Desa Krisik.

Hukum Islam memerintahkan menyempurnakan timbangan, sebagaimana dijelaskan dalam ayat 35 surat al-Isrâ'. Menurut Wahbah al-Zuhaylî, penyempurnaan takaran dan timbangan dinyatakan baik dan lebih bagus akibatnya. Artinya, menakar atau menimbang harus dilakukan dengan neraca yang benar serta tidak ada unsur penipuan. ${ }^{58}$ Penyempurnaan timbangan akan melahirkan rasa aman, ketenteraman dan kesejahteraan hidup bermasyarakat. Kesemuanya dapat tercapai melalui keharmonisan hubungan antara anggota masyarakat, antara lain bila masing-masing memberi apa yang berlebih dari kebutuhannya dan menerima yang seimbang dengan haknya. Hal ini tentu saja sangat berkaitan erat alat ukur, baik takaran maupun timbangan, serta moralitas masyarakat. Dengan kata lain, siapapun yang membenarkan dirinya mengurangi hak seseorang, hal ini akan berakibat pada tersebarnya kecurangan. Bila ini terjadi, rasa aman tidak akan tercipta. ${ }^{59^{\circ}}$

Seseorang dituntut untuk bersikap amanah dalam kondisi apapun dalam urusan takar-menakar atau menimbang barang, baik ketika

\footnotetext{
55 Tukiyem, Wawancara, Krisik, 2 Maret 2016.

56 Waris, Wawancara.

57 Tukiyem, $W$ awancara.

58 Wahbah al-Zuhaylî, dkk., Ensiklopedia Al-Qur'an (Jakarta: Gema Insani, 2007), 286.

${ }^{59}$ M. Quraish Shihab, Tafsir al-Misbah: Pesan, Kesan, dan Keserasian al-Qur'an, Vol. 7 (Jakarta: Lentera Hati, 2002), 463.
} 
melakukan transaksi perniagaan, termasuk jual beli maupun hal-hal lain. ${ }^{60}$ Maka dari itu dalam penimbangan tidak diperkenankan untuk menakar dengan dua takaran atau menimbang dengan dua timbangan, yakni timbangan pribadi untuk umum. Maksudnya timbangan untuk menguntungkan diri sendiri dan khusus bagi orang-orang yang disenanginya, dan timbangan untuk orang lain. Maksudnya, apabila untuk dirinya sendiri dan pengikutnya dia memenuhi timbangan, tetapi untuk orang lain dia mengurangi. ${ }^{61}$

Penjelasan di atas menegaskan bahwa memotong atau mengurangi timbangan merupakan bentuk kecurangan. Sementara itu dalam kasus praktik jual beli di Desa Krisik, potongan timbangan didasarkan atas kesepakatan yang diketahui oleh kedua pihak yang bertransaksi. Proses penimbangan disaksikan bersama secara langsung oleh petani dan tengkulak. Penimbangan juga dilakukan dengan satu timbangan, yaitu ketika tengkulak membeli sayur dari petani menggunakan timbangan yang sama dengan ketika tengkulak menjual sayur tersebut ke pasar. Artinya, tengkulak tidak pernah memenuhi atau juga mengurangi timbangan untuk mencari keuntungan untuk dirinya sendiri.

Bagi penulis, pemotongan timbangan yang terjadi dalam praktik jual beli sayur di Desa Krisik tidak termasuk mengurangi timbangan seperti dalam surat al-Isrâ' ayat 35. Dalam ayat tersebut yang dimaksud pengurangan timbangan adalah dilakukan dengan cara curang untuk mendatangkan keuntungan hanya bagi salah satu pihak, sedangkan potongan dalam praktik jual beli sayur di Desa Krisik dilakukan dengan dasar kesepakatan, diketahui oleh kedua pihak dan hal ini dilakukan agar kedua belah pihak tidak merugi. Pemotongan timbangan dalam praktik jual beli sayur di desa Krisik menimbulkan maslahah bukan madarrah. Dikatakan maslahah karena petani dan tengkulak sama-sama untung. Jika tidak ada potongan timbangan, madarrah justru akan timbul, yaitu kerugian pada pihak tengkulak. Jika tengkulak merugi, ia tidak akan bisa membayar petani yang, pada gilirannya, juga hanya akan menimbulkan kerugian bagi petani.

Meskipun pemotongan timbangan dalam praktik jual beli sayur di Desa Krisik tampaknya bertentangan dengan dalil teks surat al-Isrâ'

\footnotetext{
${ }^{60}$ Muhammad Sayyid Yusuf dan Ahmad Durrah, al-Qur'an dan Penerapannya, terj. Abu Akbar Ahmad (Jakarta: Rehal Publika, t.th.), 72.

${ }^{61}$ Yusuf Qardhawi, Halal dan Haram dalam Islam, terj. Abu Sa'id al-Falahi (Jakarta: Rabbani Press, Cet. 5, 2005), 367.
} 
ayat 35, namun ia tergolong maslahaḥ mursalah. Dalam Uṣ̂ul al-Fiqh, maslahạ mursalah merupakan dasar hukum bagi perbuatan yang belum ada ketentuannya dalam al-Qur'ân dan Ḥadith namun mendatangkan lebih banyak manfaat daripada mudarat. Pemotongan timbangan di kalangan petani dan tengkulak Desa Krisik merupakan jenis persyaratan yang sesuai dengan tuntutan akad. Jika petani tidak menyetujui pemotongan timbangan, maka tidak ada tengkulak yang mau membeli sayur tersebut, karena sayur yang dijual masih dalam keadaan kotor bercampur tanah dan ada pula yang kualitasnya jelek, sehingga perlu disortir terlebih dahulu. Jika tidak dipotong timbangannya, maka tengkulak akan mengalami kerugian yang akhirnya juga akan merugikan petani.

\section{Penetapan Harga dalam Praktik Jual Beli Sayur di Desa Krisik}

Dalam ekonomi Islam, harga ditentukan oleh permintaan (demand) dan penawaran (supply). Peningkatan permintaan terhadap suatu barang cenderung menjadikan harga barang tersebut naik dan mendorong produsen untuk memproduksi barang lebih banyak. Masalah kenaikan harga timbul karena ketidakseimbangan antara permintaan dan penawaran. ${ }^{62}$ Para ulama figh diantaranya, Abû Yûsuf berpendapat bahwa ketika terjadi kelangkaan barang maka harga cenderung akan tinggi, sedangkan pada saat barang tersebut melimpah, maka harga cenderung untuk turun atau lebih rendah. ${ }^{63} \mathrm{Di}$ samping itu juga adanya variabel lain yang mempengaruhi permintaan dan penawaran.

Seperti halnya praktik jual beli sayur di Desa Krisik, ketika sayur dalam keadaan langka, tengkulak berlomba-lomba mendapatkan dagangan sayur untuk memenuhi permintaan pasar. Tengkulak akan menaikkan harga sayur untuk menarik petani menjual sayurnya pada tengkulak. Terkadang ketika sayur sudah dalam keadaan langka, petani yang masih mempunyai sayur tidak lantas langsung dipanen, tetapi menunggu harga naik sehingga keuntungan yang didapat petani akan semakin banyak. Hal ini seperti ungkapan Ibn Khaldûn: "Keuntungan yang kecil akan membuat pedagang lesu karena penjual tidak bergairah. Sebaliknya bila harga tinggi pasar juga lesu karena pembeli

62 Rozalinda, Ekonomi Islam: Teori dan Aplikasinya pada Aktivitas Ekonomi (Jakarta: Rajawali Press, 2014), 154.

63 Adiwarman A. Karim, Sejarah Pemikiran Ekonomi Islam (Jakarta: Raja Grafindo Persada, Cet. 5, 2012), 249-250. 
tidak semangat". ${ }^{4}$ Dari ungkapan tersebut dapat diketahui bahwa petani lebih bersemangat menjual sayur karena mendapatkan keuntungan banyak. Sedangkan tengkulak ketika menjual sayur di pasar dengan harga tinggi, pembeli tidak semangat membeli, maka permintaan akan turun. Untuk mengembalikan gairah beli masyarakat, maka harga akan diturunkan dan begitu pula selanjutnya.

Menurut Ibn Taymîyah, kenaikan harga disebabkan penawaran yang turun akibat inefisiensi produksi, penurunan impor atau tekanan pasar. Jika penawaran turun, sedangkan permintaan meningkat maka harga akan naik, begitupula sebaliknya. ${ }^{65}$ Karena jumlah sayur yang dimiliki petani berkurang, bahkan cenderung langka, tentu berdampak pada berkurangnya penawaran sayur dari petani, sedangkan kebutuhan atau permintaan dari tengkulak tetap, bahkan meningkat tentu akan meningkatkan harga dari sayur tersebut.

Harga jual beli sayur di Desa Krisik sedikit berbeda di mana meskipun permintaan tetap dan cenderung naik pada keadaan tertentu harga akan cenderung tetap pada harga standar dan tidak mengalami kenaikan. Hal ini terjadi karena adanya tengkulak dari luar Ponorogo (seperti dari Magetan) yang ikut membeli sayur di Desa Krisik dan mereka mau menawar dengan harga tinggi. Petani tentu akan lebih memilih menjual sayurnya kepada tengkulak yang mau membeli sayur dengan harga tinggi, sehinggga petani akan mendapatkan keuntungan yang lebih besar.

Selain itu telah ketahui oleh banyak orang bahwa sayur dari Magetan dikenal sebagai sayur yang berkualitas, sehingga banyak masyarakat yang lebih memilih sayur dari Magetan daripada sayur dari Pudak. ${ }^{66}$ Banyaknya orang mengenal kualitas suatu barang akan mempengaruhi daya beli masyarakat. Dengan begitu permintaan akan terus naik, walaupun harga juga naik, sehingga meskipun pedagang Magetan menjual sayur dengan harga tinggi akan tetap laku. Karena permintaan terus naik sedangkan penawaran sayur sudah tidak bisa memenuhi permintaan pembeli, maka pedagang Magetan mencari sayur ke Pudak untuk memenuhi permintaan pembelinya. Untuk menarik masyarakat Pudak, termasuk Desa Krisik, agar mau menjual

\footnotetext{
${ }^{64}$ Ibid., 188.

65 Ibid., 187.

${ }^{66}$ Wahid, Wawancara.
} 
sayur kepadanya, tengkulak dari Magetan membeli dengan harga lebih tinggi daripada tengkulak lokal. ${ }^{67}$

Tengkulak lokal hanya berani membeli dengan harga standar, dan dari keterangan di atas dapat diketahui bahwasa harga sayur di pasar berbeda antara yang berasal dari Magetan dengan sayur asli Pudak. Jika tengkulak lokal ikut menaikkan harga sayur, mereka akan mengalami kerugian. Untuk menghindari hal tersebut, tengkulak lokal tetap membeli dengan harga standar, walaupun barang semakin langka dan permintaan terus tinggi. ${ }^{68}$

Dari keterangan di atas, penulis menyimpulkan bahwa praktik jual beli sayur di Desa Krisik sesuai dengan hukum penawaran dan permintaan dikarenakan dipengaruhi oleh faktor-faktor penawaran dan permintaan. Hal ini senada dengan pendapat Ibn Taymîyah: "Penentuan harga mempunyai dua bentuk, ada yang boleh dan ada yang haram. Penetapan harga yang tak adil dan haram berlaku atas naiknya harga akibat kompetisi kekuatan pasar yang bebas yang mengakibatkan terjadinya kekurangan suplai dan menaikkan permintaan". ${ }^{9}$ Pembelian sayur dengan harga standar bukan merupakan ulah tengkulak yang semata-mata ingin mencari keuntungan. Penetapan harga ini terjadi karena keadaan pasar, tanpa adanya campur tangan tengkulak maupun pemerintah. Penetapan harga seperti ini merupakan penetapan harga yang diperbolehkan dalam fiqh.

\section{Penutup}

Praktik jual beli sayur di Desa Krisik Kecamatan Pudak menggunakan akad jual beli dan wakâlah, karena praktik jual beli sayur tersebut telah memenuhi syarat dan rukun dari akad jual beli maupun wakâlah. Adanya pembayaran setelah sayur terjual di pasar, meskipun disertai tempo tetapi tidak ada penambahan pembayaran, serta pembayaran yang tidak sesuai dengan kesepakatan awal ketika harga di pasar mengalami fluktuasi, diperbolehkan dalam wakâlat mutlaqah. Hal ini karena dalam praktik tersebut biasanya penurunan harga hanya berkisar Rp. 500 dan tengkulak lain juga tidak ada yang mau membeli dengan harga lebih tinggi.

${ }^{67}$ Kinul, Wawancara, Krisik, 5 Maret 2016.

${ }^{68}$ Ibid.

${ }^{69}$ Yusuf Qardhawi, Norma dan Etika Ekonomi Islam, terj. Zainal Arifin dan Dahlia Husin (Jakarta: Gema Insani, 1997), 257. 
Potongan timbangan dalam praktik jual beli di Desa Krisik diperbolehkan dalam tinjauan figh. Hal ini karena potongan timbangan yang dilakukan bukan sebuah kecurangan yang dilakukan tengkulak tetapi sebuah solusi agar petani dan tengkulak sama-sama untung. Penetapan harga dalam praktik jual beli sayur di Desa Krisik juga telah sesuai dengan hukum fiqh karena harga tersebut terbentuk dari permintaan dan penawaran yang tidak seimbang dan bukan dikarenakan adanya distorsi pasar, terutama perilaku dari tengkulak maupun petani untuk mencari keuntungan semata.

\section{Daftar Rujukan}

\section{A. Buku}

Basyir, Ahmad Azhar. Asas-asas Hukum Muamalah Hukum Perdata Islam. Yogyakarta: UII Press, 2000.

Dhimyauddin, Djuwaini. Pengantar Fiqih Muamalah. Yogyakarta: Pustaka Pelajar, 2008.

Hasan, M. Ali. Berbagai Macam Transaksi dalam Islam. Jakarta: Raja Grafindo Persada, Cet. 2, 2004.

Huda, Qomarul. Fiqih Muamalah. Yogyakarta: Teras, 2011.

Karim, Adiwarman A. Sejarah Pemikiran Ekonomi Islam. Jakarta: Raja Grafindo Persada, Cet. 5, 2012.

Laskar Pelangi, Tim. Metodologi Figih Muamalah: Diskursus Metodologis Konsep Interaksi Sosial Ekonomi. Kediri: Lirboyo Press, Cet. 2, 2013.

Mardani. Fiqih Ekonomi Syariah. Jakarta: Kencana Prenada Media Group, Cet. 2, 2013.

Mas'ud, Ibnu dan Abidin, Zainal. Fiqih Madzab Syafii Buku 2: Muamalah, Munakahat, Jinayat. Bandung: Pustaka Setia, 2007.

Nawawi, Ismail. Fiqih Muamalah Klasik dan Kontemporer: Hukum Perjanjian, Ekonomi, Bisnis dan Sosial. Bogor: Ghalia Indonesia, 2002.

Qardhawi, Yusuf. Halal dan Haram dalam Islam, terj. Abu Sa'id alFalahi. Jakarta: Rabbani Press, Cet. 5, 2005.

----. Norma dan Etika Ekonomi Islam, terj. Zainal Arifin dan Dahlia Husin. Jakarta: Gema Insani, 1997.

Rahman, Afzalur. Doktrin Ekonomi Islam IV. Yogyakarta: Dana Bakti Wakaf, 1996.

Rozalinda, Ekonomi Islam: Teori dan Aplikasinya pada Aktivitas Ekonomi. Jakarta: Rajawali Press, 2014.

Sabiq, Sayyid. Fiqib Sunnah, Vol. 12, terj. Kamaludin A. Marzuki. Bandung: Al-Ma'arif, 1987. 
Shihab, M. Quraish. Tafsir al-Misbah: Pesan, Kesan, dan Keserasian alQur'an, Vol. 7. Jakarta: Lentera Hati, 2002.

Sudarsono, Pokok-Pokok Hukum Islam. Jakarta: Raja Grafindo Persada, 2002.

Suhendi, Hendi. Fiqih Muamalah. Jakarta: Rajawali Press, Cet. 8, 2013.

Suwarjin. Ushul Fiqih. Yogyakarta: Teras, 2012.

Syafe'i, Rahmat. Fiqib Muamalah. Bandung: Pustaka Setia, 2006.

Wahbah al-Zuhaylî, dkk., Ensik.lopedia Al-Qur'an. Jakarta: Gema Insani, 2007.

Yusuf, Muhammad Sayyid dan Durrah, Ahmad. Al-Qur'an dan Penerapannya, terj. Abu Akbar Ahmad. Jakarta: Rehal Publika, t.th.

\section{B. Wawancara}

Darmi. Wawancara. Krisik, 29 Februari 2016.

Gito. Wawancara. Krisik, 20 Februari 2016.

Katemi. Wawancara. Krisik, 26 Februari 2016.

Kinul. Wawancara. Krisik, 5 Maret 2016.

Loso. Wawancara. Krisik, 27 Februari 2016.

Ratmi. Wawancara. Krisik, 17 Februari 2016.

Tukiyem. Wawancara. Krisik, 2 Maret 2016.

Wahid. Wawancara. Krisik, 15 Februari 2016.

Waris. Wawancara. Krisik, 29 Februari 2016.

Warna (Kades Desa Krisik). Wawancara. Krisik, 29 Februari 2016. 